\title{
Mapping of land potentially for maize plant in Madura Island-Indonesia using remote sensing data and geographic information systems (GIS)
}

\author{
Suhartono ${ }^{1 *}$, Agoes Soegianto ${ }^{2 *}$ and Achmad Amzeri ${ }^{1}$ \\ ${ }^{1}$ Faculty of Agriculture, University of Trunojoyo Madura, Indonesia \\ ${ }^{2}$ Department of Biology, Faculty of Science and Technology, Universitas Airlangga, \\ Surabaya, Indonesia
}

(Received 26 February, 2020; Accepted 22 June, 2020)

\begin{abstract}
Maize productivity in Indonesia was still low (5.241 tons/ha) compared to the average of the ten largest maize producing countries in the world (6.179 tons $/$ ha). The potential for maize on the island of Madura is approximately 360,000 hectares. The potential for maize cultivation in Madura continues to decrease in land quality due to improper land clearing and land-use change. The purpose of this research was to make a map of land suitability for maize using Remote Sensing Data and Geographic Information System (GIS). The land suitability method for maize plants used satellite imagery as a data source, supported by fieldwork and secondary data. Data analysis using Geographic Information Systems (GIS). The results of the analysis of land suitability modeling based on agroecosystem potential found that most of the Madura area was suitable for maize cultivation. Madura island had a land area of 456,622.3ha for maize cultivation, where 170.379 .5 (15.4\%) was very appropriate, 211.412 .3 ha $(46.3 \%)$ was appropriate, $160,098.6(35.1 \%)$ was less appropriate, and $14,732.0$ ha $(3.2 \%)$ was not appropriate.
\end{abstract}

Key words : Geographic Information System (GIS), Landsat satellite imagery, Land suitability evaluation, maize plant.

\section{Introduction}

The demand for maize in the world increased by 129 million tons every year (Edgerton, 2009). The increasing demand is caused by the function of maize other than as food or feed but becomes an essential component in the production of various products such as adhesives, ethanol, cosmetics, soaps, and other industrial products (Ranum et al., 2014; Nugroho, 2015). Increased demand for maize in the world must be balanced with an increase in maize production in maize-producing countries in the world. Indonesia was the most significant maize producing country in Southeast Asia, with a production of 30.055 million tons in 2018 (BPS, 2019).
However, maize productivity in Indonesia was still low $(5,241$ tons/ha) compared to the average of the ten largest maize producing countries in the world (6,179 tons/ha) (Agriculture Ministry of Indonesia, 2019). The low productivity of maize is caused by (1) the decrease in land quantity, in general land in Indonesia has experienced a significant decline due to land conversion, (2) degradation of agricultural land in the watershed area, (3) a decrease in the quality of agricultural land, especially rice fields, due to improper land management (Mujiyo et al., 2008).

Madura Island-Indonesia has an agricultural area of around 400 thousand hectares, which is dominated by rainfed rice fields with rainfall above 200 
mm from December to April, with low soil fertility and low productivity (BPS, 2019). The potential for maize on the island of Madura is approximately 360,000 hectares (Roesmarkam et al., 2006; Kasryno et al., 2007). The potential for maize cultivation in Madura continues to decrease in land quality due to improper land clearing and land-use change. One effort to overcome these problems is to identify and map land uses periodically. Evaluation results can be used for consideration in the formulation of spatial planning policies by prioritizing the existence of agricultural land (Directorate of Land Processing, 2006)

Remote sensing technology combined with geographic information systems (GIS) is needed for identification and mapping of land use, which fast and accurate. Remote sensing technology has proven to be a useful tool in detecting land use and land cover changes. Al Rahami et al. (2020) used remote sensing technology in classifying topographic changes in the al-Ashari lake region, Iraq. Salih (2018) used remote sensing technology to map land cover types for sub-areas in AlAhasaa Oasis, Saudi Arabia. The purpose of this research was to make a map of land suitability for maize using Remote Sensing Data and Geographic Information System (GIS).

\section{Methodology}

The materials used for remote sensing of geographic information systems and the characteristics of Madura agro-ecosystems were Aster Image of Madura region, Map of Indonesia covers the area of Madura on a scale of 1: 25,000, land map scale 1: 250,000 , secondary data (rainfall data). The tools used were ArcGis Software, Envi 4.4, Surfer 8, GPS, roomy cameras, and measuring devices (soil drill, soil test kit, $\mathrm{pH}$ meter).

The initial phase of the study was mapping the characteristics of Madura agroecosystems. The stages of analysis in mapping the characteristics of agroecosystems were as follows:

The description of the implementation of research-based on the research scheme in the picture above:

1. Pre-processing satellite imagery. At this stage consists of two stages: radiometric and geometry correction. Radiometry correction aims to improve the visual quality of the image and, at the same time, correct the pixel values that are not appropriate. Geometry Correction aims to put the position of objects in the image by the actual position in the field. The results of this initial process are corrected images.

2. Interpretation of land use. Land use interpretation from digital images of Landsat ETM + and Aster. The interpretation of land use refers to the classification of Malingreau (1982), i.e., Forests, mangroves, settlements/buildings, rice fields, rivers/lakes, fishponds, open land, and moor.

3. Digital Elevation Model (DEM) Extraction. DEM data are obtained from the contours of the RBI map and extraction from Aster imagery. Contour data from RBI is interpolated using ArcGis software with extension topo to raster.

4. Making slope maps obtained from DEM data. DEM data in the form of height data are derived to get slope data. Slope data is calculated in percent (\%). Slope data are classified into five slope classes: flat, sloping, slightly sloping, steep, and very steep.

5. Making maps of soil types obtained from digitized soil maps. The digitalized soil maps were validated with satellite images and validated with soil sample data from the field.

6. Making a rainfall map. The process of making a rainfall map was as follows: Process rainfall data received from the measurement station to extract the average annual rainfall data $(\mathrm{mm} /$ year). Plotting the coordinates of the measurement station position so that the point of the measurement station position layer is formed. Incorporating (data entry) the mean annual rainfall attribute data at the coordinate layer of the measurement station. Interpolate (spatial analysis) annual average rainfall data to form a rainfall layer (polygon). Classifying rainfall data.

7. Field checking. This activity carried out to determine the accuracy of the classification and data collection that can not be obtained through image analysis. Field data is also used to test the accuracy of map interpretation of satellite imagery.

8. Make a table of soil observations. In this activity, the traits of the soil were observed. Soil sampling is done by stratified sampling method, where the strata were land units. Land units are obtained through overlapping height maps, slope maps, land use maps, land type 


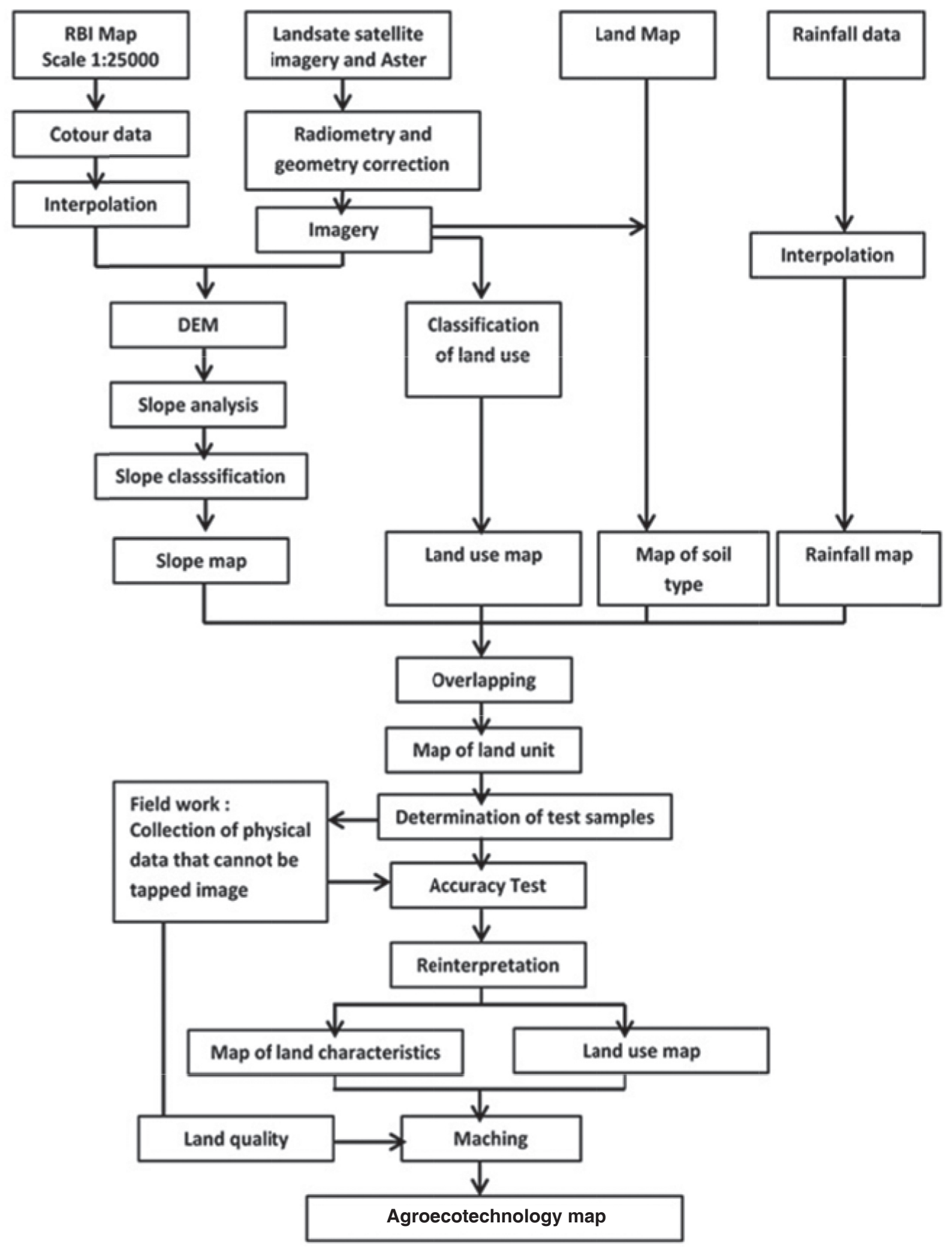

Fig. 1. Step of preparing land suitability maps for maize 
maps, and rainfall maps. The observed soil traits consist: (a) soil color, determined by the Munsell color scale, (b) soil depth, divided into four depth classes according to PPT (1981), on the field, the sufficient depth of the soil is measured through drilling with a ground drill, (c) soil texture, based on classification results according to the USDA (1951) in the FAO Staff CSR (1983), (d) soil acidity (pH), determined by the $\mathrm{pH}$ indicator in the soil solution plus water $\left(\mathrm{H}_{2} \mathrm{O}\right)$.

9. Classify land suitability for certain types of plants by comparing land characteristics and land quality, as shown in the table below:

10. Processing land suitability for maize. This activity is carried out in stages: Classifying land characteristics into land quality for land suitability assessment by land suitability guidelines referred to in CRS / FAO Staff (1983). Arrange a unit map based on the physical parameters of the land (height, slope, land use, soil type, rainfall, and describe the quality of land on each land unit). Classifying land suitability for maize needs by matching the quality of land for each unit of land.

\section{Results and Discussion}

\section{Land Use Map from Satellite Imagery}

Land use maps are made from Landsat and ASTER images, images used by level 1B on ASTER, and level $1 \mathrm{G}$ on Landsat 7 ETM +. At this level, the image has been corrected geometry, so no geometry correction is done. Radiometry correction is done by changing digital values into radiance. The purpose of radiometric correction was to improve the visual quality of the image. The image used for land use interpretation was the Landsat and ASTER imagery, as in Figure 2.

Making color composite images is needed to obtain a better visual picture of the object. This composite image will be used for sampling areas for classification, sampling through images, and as a tool in field checking. The combination of the composition of the composite image based on red, green, and blue in order to obtain the best appearance. So that land cover objects can be identified and differentiated more clearly and easily.

Land use classification using the classification of Malingreau (1982), which was modified, was adjusted to the needs of the study as in Table 2. In this study, the classification of land use is grouped into eight classes, i.e., Forests, mangroves, settlements / buildings, rice fields, rivers/lakes, fishponds, open land, and moor.

Based on the results of the classification in Table 2 , it can be seen that the entire image can be explained. The results of land use classification in Madura show that open land is the dominant land cover reaching $242,415.3$ ha (53.1\%), moor reached $82,552.1$ ha $(18.1 \%)$, rice fields reached $75,237.2$ ha $(16.5 \%)$. Settlements/buildings reached $33,647.0$ ha $(7.4 \%)$, forests reached $8,982.0$ ha $(1.9 \%)$, fishponds reached $8,299.7$ ha $(1.8 \%)$, mangroves reached $4,984.4$ ha $(1.1 \%)$, river/lakes reached $594.4(0.1 \%)$.

Table 3 shows that the utilization of agricultural areas (rice fields and gardens) in each district ranged from $12.1 \%$ - 20.6\%, wherein Bangkalan District was $15.7 \%$, Sampang District was $12.1 \%$,

Table 1. Land quality and land characteristics

\begin{tabular}{|c|c|}
\hline Land quality & Land characteristics \\
\hline Temperature $(\mathrm{t})$ & Annual average temperature $\left({ }^{\circ} \mathrm{C}\right)$ \\
\hline Water availability (w) & $\begin{array}{ll}- & \text { Dry month } \\
\text { - } & \text { Average annual rainfall }(\mathrm{mm})\end{array}$ \\
\hline Root condition (r) & $\begin{array}{ll}\text { - } & \text { Class drainage } \\
\text { - } & \text { Soil Texture (surface part) } \\
\text { - } & \text { Depth of roots }(\mathrm{cm})\end{array}$ \\
\hline Power holding nutrients (f) & $\begin{array}{ll}- & \text { CEC }(\mathrm{me} / 100 \mathrm{~g}) \\
- & \text { Soil pH }\end{array}$ \\
\hline Availability of nutrients (f) & $\mathrm{N}$ total $(\%), \mathrm{P}_{2} \mathrm{O}_{5}, \mathrm{~K}_{2} \mathrm{O}$ \\
\hline Poisoning $(\mathrm{x})$ & Salinity \\
\hline Field (s) & $\begin{array}{ll}- & \text { Slope } \\
\text { - } & \text { rocks on the surface } \\
\text { - } & \text { Rock outcrops }\end{array}$ \\
\hline
\end{tabular}




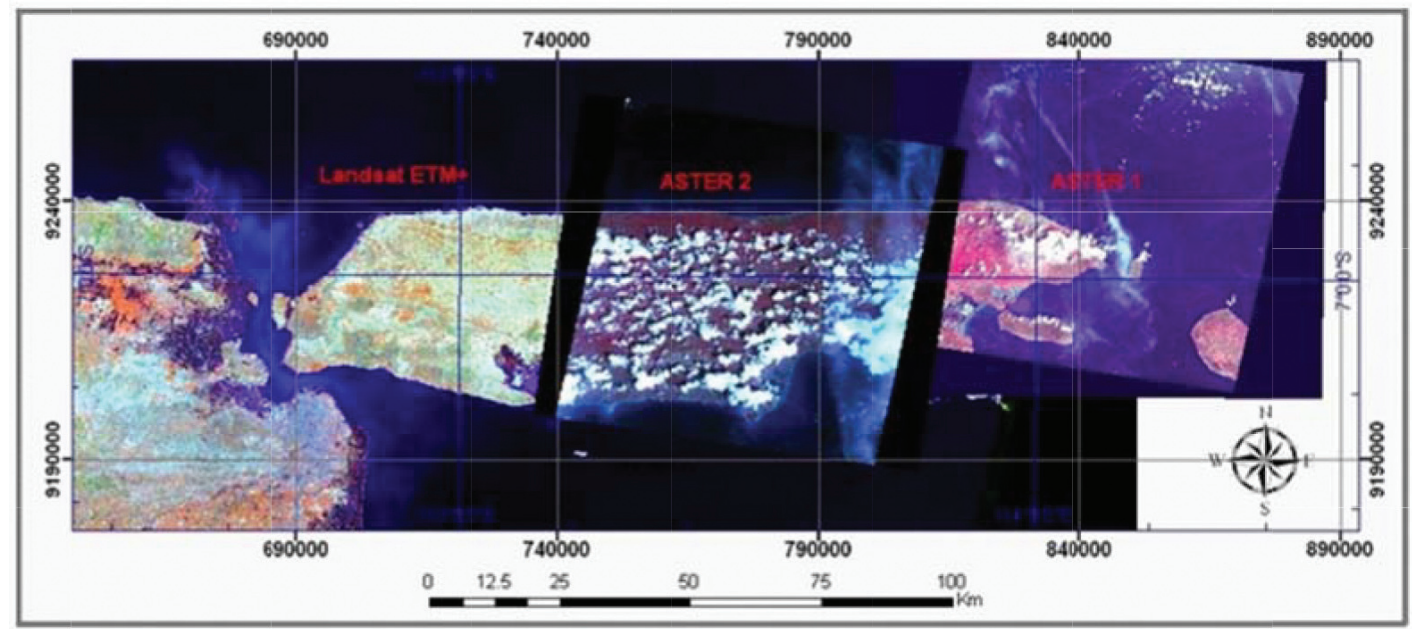

(a)

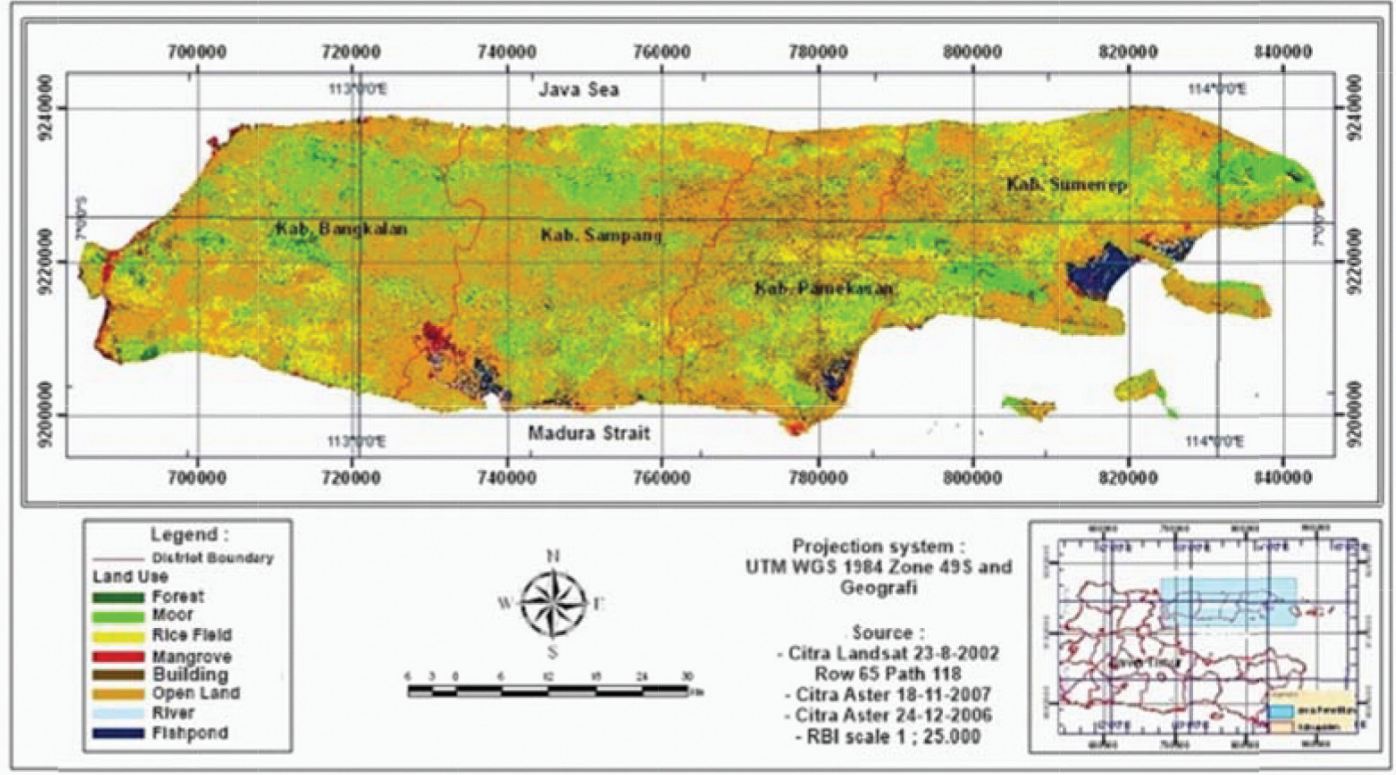

(b)

Fig 2. (a) Landsat ETM + satellite imagery (23-8-2002), ASTER 1 imagery (24-12-2006) and ASTER 2 imagery (11-112007); (b) Land use map resulting from interpretation of satellite imagery.

Table 2. The area of land use that results from the classification of satellite imagery

\begin{tabular}{llcc}
\hline No & Land Use Classification & Land area (ha) & Percentage (\%) \\
\hline 1 & Forest & $8,982.0$ & 1.9 \\
2 & Mangrove & $4,894.4$ & 1.1 \\
3 & Settlements/buildings & $33,647.1$ & 7.4 \\
4 & Rice field & $75,237.3$ & 16.5 \\
5 & River/lakes & 594.4 & 0.1 \\
6 & Fishponds & $8,299.7$ & 1.8 \\
7 & Open land & $242,415.3$ & 53.1 \\
8 & Moor & $82,552.1$ & 18.1 \\
& Total & $456,622.3$ & 100.0 \\
\hline
\end{tabular}


Table 3. The area of land use in four districts of Madura-Indonesia

\begin{tabular}{|c|c|c|c|c|c|c|c|c|c|}
\hline \multirow[t]{2}{*}{ No } & \multirow[t]{2}{*}{ Land Use Classification } & \multicolumn{8}{|c|}{ District } \\
\hline & & $\begin{array}{l}\text { Bangkalan } \\
\text { (ha) }\end{array}$ & $\%$ & $\begin{array}{c}\text { Sampang } \\
\text { (ha) }\end{array}$ & $\%$ & $\begin{array}{c}\text { Pamekasan } \\
\text { (ha) }\end{array}$ & $\%$ & $\begin{array}{l}\text { Sumenep } \\
\text { (ha) }\end{array}$ & $\%$ \\
\hline 1 & Forest & 5,119 & 3.9 & 1,716 & 1.4 & 580 & 0.7 & 1,466 & 1.2 \\
\hline 2 & Mangrove & 2,513 & 1.9 & 1,079 & 0.9 & 391 & 0.5 & 1,012 & 0.8 \\
\hline 3 & Settlements/buildings & 5,176 & 4.0 & 6,147 & 5.0 & 11,786 & 14.4 & 11,538 & 9.5 \\
\hline 4 & Rice field & 20,476 & 15.7 & 14,866 & 12.1 & 13,939 & 17.1 & 24,957 & 20.6 \\
\hline 5 & River/lakes & 5 & 0.0 & 374 & 0.3 & 35 & 0.0 & 281 & 0.2 \\
\hline 6 & Fishponds & 732 & 0.6 & 2,307 & 1.9 & 1,221 & 1.5 & 3,940 & 3.2 \\
\hline 7 & Open land & 68,740 & 52.8 & 70,234 & 56.9 & 40,313 & 49.3 & 53,127 & 43.8 \\
\hline \multirow[t]{2}{*}{8} & Moor & 27,357 & 21.0 & 26,640 & 21.6 & 13,480 & 16.5 & 25,075 & 20.7 \\
\hline & Total & 130,119 & 100.0 & 123,363 & 100.0 & 81,744 & 100.0 & 121,397 & 100.0 \\
\hline
\end{tabular}

Source: Satellite image analysis results

Pamekasan District was 17.1\%, and Sumenep District was $20.6 \%$. Utilization of land for agricultural land was not optimal, proven that most of the area was still in the form of open land, reaching $49.3 \%$ $56.9 \%$ and moor reaching $16.5 \%-21.5 \%$.

\section{Slope map}

Slope interpretation used digital contour map data for Digital Elevation Model (DEM) processing. Contour data were obtained from RBI data at a scale of 1: 25,000 , with a contour interval of $12.5 \mathrm{~m}$. Contour maps can be seen in Figure 3a.

The DEM map is prepared using the topo to raster tool, where interpolation in this tool used the minimum curvature method. The DEM size is adjusted to the resolution of the two images, which was $30 \mathrm{~m}$. Slope maps are obtained from the DEM map analysis using 3D Analyst tools. The results of the DEM map can be seen in Figure 3b. The concept of this tool was to build a slope map based on the calculation of the maximum change between each cell. The resulting slope map used units $\%$.

The slope classification is used according to the modified Arsyad (1989) method. In this classification are grouped into seven classes, i.e. $<3 \%, 3-5 \%$, $5-8 \%, 8-16 \%, 16-25 \%, 25-30 \%$ and $>30 \%$. The interpretation results showed that the slope conditions in Madura were mostly on slope conditions $<3 \%$ reaching an area of $257,146.1$ ha or $56.3 \%$ of the area of Madura (Table 4). 3-5\% slope reached 62,062.5 ha or $13.6 \%$. $5-8 \%$ slope reached $51,225.3$ ha $(11.2 \%)$, slope $8-16 \%$ reached $58,772.8$ ha $(12.9 \%)$ and $16-25 \%$ reached $19,088.5$ ha $(4.2 \%), 25-30 \%$ slope reached $2,861.6$ or $0,6 \%$ and slopes $>30 \%$ reached $5,465.4$ ha $(1.2 \%)$.
Table 4. Slope area analysis results in Madura-Indonesia

\begin{tabular}{llcc}
\hline No & $\begin{array}{l}\text { Slope classification } \\
(\%)\end{array}$ & $\begin{array}{c}\text { Land } \\
\text { area (ha) }\end{array}$ & $\begin{array}{c}\text { Percentage } \\
(\%)\end{array}$ \\
\hline 1 & $<3 \%$ & $257,146.3$ & 56.3 \\
2 & $3-5 \%$ & $62,062.5$ & 13.6 \\
3 & $5-8 \%$ & $51,225.3$ & 11.2 \\
4 & $8-16 \%$ & $58,772.8$ & 12.9 \\
5 & $16-25 \%$ & $19,088.5$ & 4.2 \\
6 & $25-30 \%$ & $2,861.6$ & 0.6 \\
7 & $>30 \%$ & $5,465.4$ & 1.2 \\
& Total & $456,622.3$ & 100.0 \\
\hline
\end{tabular}

In Table 5, there was no significant difference in slope conditions in each district. The slope at condition $<3 \%$ is the most dominant, reaching an area of between 47.4 to $63.5 \%$ of the area of each district in Madura, where Bangkalan reached 82,608 ha $(63.5 \%)$, Sampang reached 73,722 ha $(59.8 \%)$, Pamekasan reached 42,292 (51.7\%), and Sumenep reached 57,524 (47.4\%).

\section{Rainfall Map}

A rainfall map is obtained from the analysis of field measurement data for approximately ten years. Measurement data is obtained in several sub-districts in each district and was modeled using the interpolation method. The tools used for this analysis were the topo to raster tool, where the interpolation in this tool used the minimum curvature method. Interpolation results have obtained a map of rainfall in Madura, as shown in Figures 4a and 4b.

Maps of annual and monthly rainfall can be shown in Figures $3 \mathrm{a}$ and $3 \mathrm{~b}$. The results of annual rainfall measurement data from data for ten years show that the distribution of rainfall in the Madura 
region ranges from 846.18 - $2079.31 \mathrm{~mm} /$ year. The average annual rainfall in the Madura area was $1346.89 \mathrm{~mm} /$ year. The graph of the distribution of annual rainfall data can be seen in Figure 5a. Monthly rainfall averages reached $139.21 \mathrm{~mm} /$ month. The minimum rainfall condition was 110.03 $\mathrm{mm} / \mathrm{month}$, and the maximum rainfall was 157.97 $\mathrm{mm} / \mathrm{month}$. The graph of the distribution of annual rainfall data can be seen in Figure 5b.

\section{Soil Analysis Test}

Soil analysis test is carried out to find out the soil

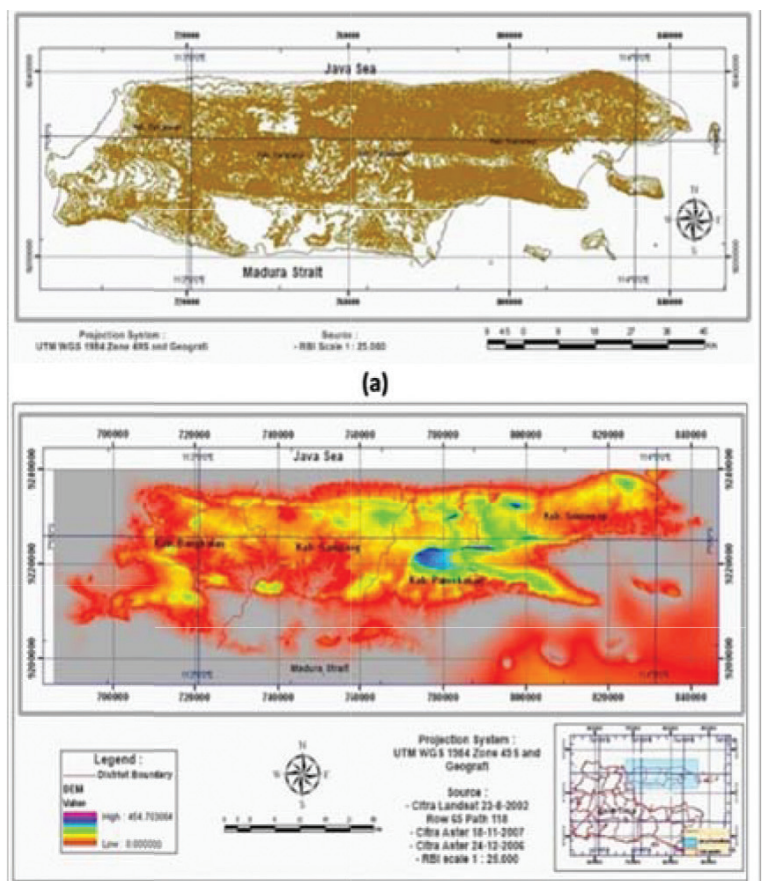

(b)

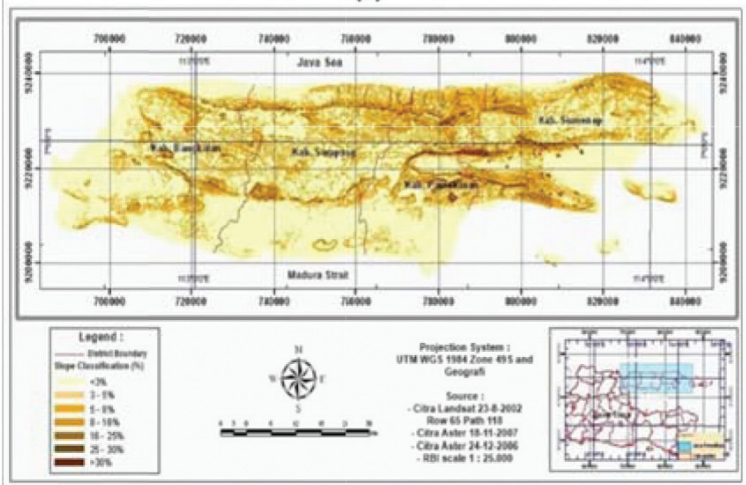

(c)

Fig. 3. (a) Map of Contours in Madura; (b) Digital Elevation Model (DEM) map as the result of interpolation from contour map; (c) Slope map is extracted from DEM in Madura. quality content, both organic and inorganic, in each different type of soil. The sampling location is shown in Figure 6. Soil analysis results showed that the average $\mathrm{pH}$ of soil $\mathrm{H}_{2} \mathrm{O}=7, \mathrm{pH} \mathrm{KCl}=6,1$. Average organic $\mathrm{C}$ content $=0.7$. Average total $\mathrm{N}$ content $=0.1$ and $\mathrm{C} / \mathrm{N}$ ratio $=7.9$. The average content of $\mathrm{C}$ olsen $=8$, while P Olsen $=8 \mathrm{mg} / \mathrm{kg}$. Average $\mathrm{K}$ content $=0.2 \mathrm{me} / 100 \mathrm{~g}, \mathrm{Na}=0.2 \mathrm{me} / 100 \mathrm{~g}, \mathrm{Ca}=12$ me / 100g, Mg = $1.7 \mathrm{me} / 100 \mathrm{~g}$, Cation Exchange Capacity $(C E C)=19.4 \mathrm{me} / 100 \mathrm{~g}$. The average number of bases $=14.1$, the average Saturation Base $=$

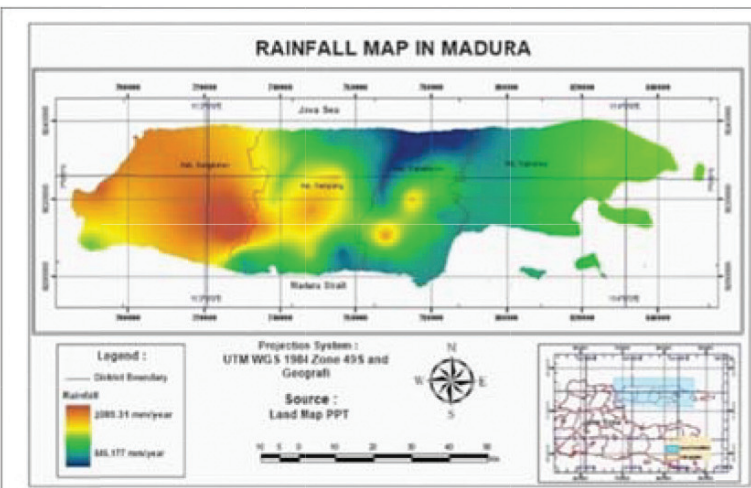

(a)

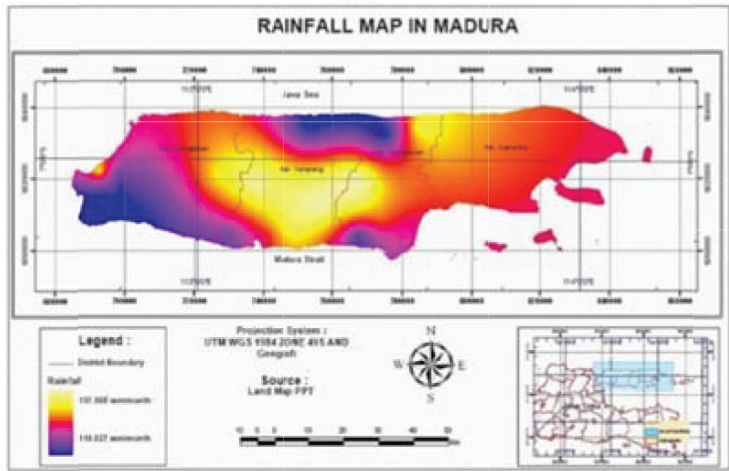

(b)

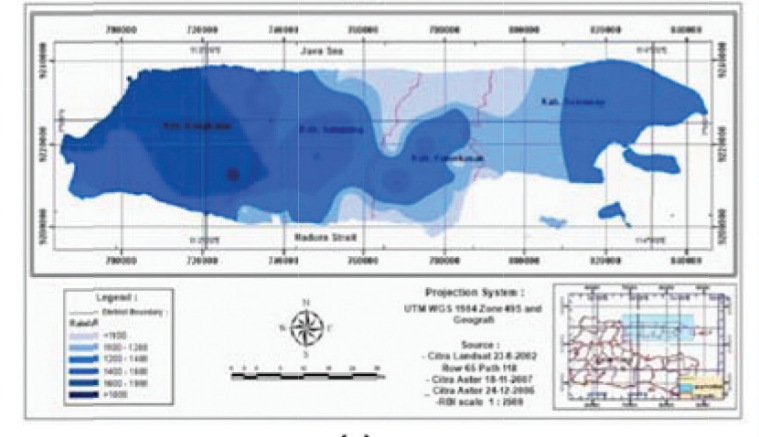

(c)

Fig 4. (a) Map of annual rainfall in Madura; (b) Map of monthly average rainfall in Madura; (c) Map of the classification of average rainfall in Madura. 


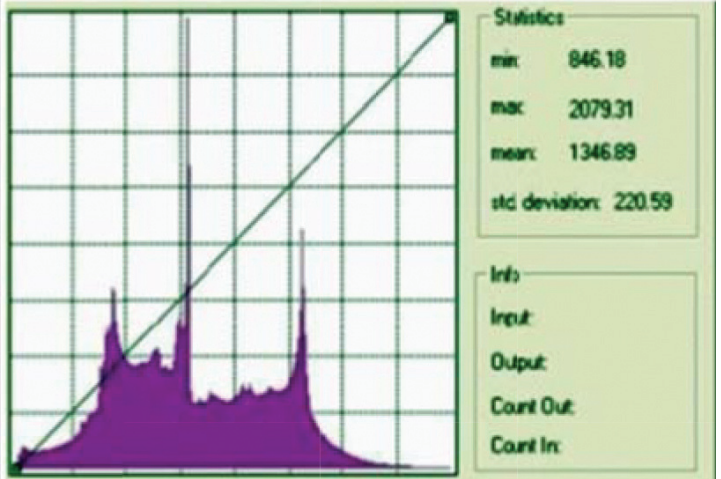

(a)

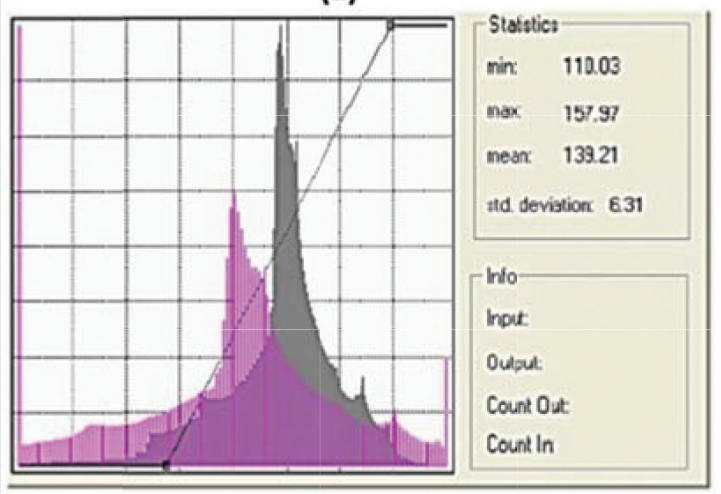

Fig. 5.(a) Graph of distribution of annual rainfall data in Madura; (b) Graph of distribution of monthly rainfall data in Madura.

$73.9 \%$. The average content of sand $=42.7 \%$, dust $=$ $29.9 \%$ and clay $=17.3 \%$.

\section{Madura Island Potential Modeling Based on Agroecosystems}

Agroecosystem modeling is done by overlapping between maps of land characteristics and land use that are equipped with land quality analysis results of soil sample tests on each soil type. Next, match- ing is based on the land suitability criteria for maize. The land suitability criteria are obtained from the Agricultural Research and Development Center for Agricultural Resources (Indonesia) that have modified. Land suitability criteria can be shown in Table 6.

\section{Maize Agroecosystem Potential}

The results of the analysis of land suitability modeling based on agroecosystem potential found that most of the Madura area was suitable for maize cultivation (Figure 7). Madura island had a land area of 456,622.3ha for maize cultivation, where $170,379.5$ $(15.4 \%)$ was very appropriate, $211,412.3$ ha $(46.3 \%)$ was appropriate, 160,098.6 (35.1\%) was less appropriate, and $14,732.0$ ha $(3.2 \%)$ was not appropriate (Table 7).

Bangkalan District had an area of 130,1188.6 ha for maize cultivation, where $14,001.8$ ha $(10.8 \%)$ was very appropriate, $60,996.7$ ha $(46.9 \%)$ was appropriate, $50,311.1$ ha $(38.7 \%)$ was less appropriate, and $4,809.0$ ha $(3.7 \%)$ was not appropriate (Table 8$)$. Sampang District had a land area of $123,362.5$ ha for maize cultivation, where $20,247.7$ ha $(16.4 \%)$ was very appropriate, $45,195.7$ ha $(36.6 \%)$ was appropriate, $54,833.0$ ha $(44.4 \%)$ was less appropriate, and $3,086.0$ ha $(2.5 \%)$ was not appropriate.

Pamekasan District had a land area of $81,744.0$ ha for maize cultivation, where $15,188.4$ ha $(18.6 \%)$ was very appropriate, $37,547.2$ ha $(45.9 \%)$ was appropriate, $25,197.0$ ha $(30.8 \%)$ was less appropriate, and $3,811.3$ ha $(4.7 \%)$ was not appropriate. Sumenep District had a land area of 121,397.2 ha for maize cultivation, where $20,941.5$ ha (17.3\%) was very appropriate, $67,672.7$ ha $(55.7 \%)$ was appropriate, $29,757.4$ ha (24.5\%) was less appropriate, and 3,025.6 ha $(2.5 .5) \%)$ was not appropriate.

Table 5. The slope area of the analysis results in 4 districts in Madura-Indonesia

\begin{tabular}{|c|c|c|c|c|c|c|c|c|c|}
\hline \multirow[t]{2}{*}{ No } & \multirow[t]{2}{*}{ Slope } & \multicolumn{8}{|c|}{ District } \\
\hline & & $\begin{array}{c}\text { Bangkalan } \\
\text { (ha) }\end{array}$ & $\%$ & $\begin{array}{c}\text { Sampang } \\
\text { (ha) }\end{array}$ & $\%$ & $\begin{array}{c}\text { Pamekasan } \\
\text { (ha) }\end{array}$ & $\%$ & $\begin{array}{l}\text { Sumenep } \\
\text { (ha) }\end{array}$ & $\%$ \\
\hline 1 & $<3 \%$ & 82,608 & 63.5 & 73,722 & 59.8 & 42,292 & 51.7 & 57,524 & 47.4 \\
\hline 2 & $3-5 \%$ & 17,653 & 13.6 & 16,115 & 13.1 & 10,482 & 12.8 & 18,813 & 15.5 \\
\hline 3 & $5-8 \%$ & 13,099 & 10.1 & 12,955 & 10.5 & 9,758 & 11.9 & 16,413 & 13.5 \\
\hline 4 & $8-16 \%$ & 12,557 & 9.7 & 14,847 & 12.0 & 11,829 & 14.5 & 18,540 & 15.3 \\
\hline 5 & $16-25 \%$ & 3,135 & 2.4 & 4,289 & 3.5 & 4,428 & 5.4 & 6,236 & 5.1 \\
\hline 6 & $25-30 \%$ & 552 & 0.4 & 770 & 0.6 & 1,076 & 1.3 & 1,363 & 1.1 \\
\hline 7 & $>30 \%$ & 514 & 0.4 & 664 & 0.5 & 1,076 & 2.3 & 2,508 & 2.1 \\
\hline & Total & 130,119 & 100.0 & 123,363 & 100.0 & 81,744 & 100.0 & 121,397 & 100.0 \\
\hline
\end{tabular}


Table 6. Land suitability criteria for maize cultivation

\begin{tabular}{|c|c|c|c|c|}
\hline \multirow[t]{2}{*}{ Land characteristics } & \multicolumn{4}{|c|}{ Land suitability class } \\
\hline & S1 & S2 & S3 & $\mathrm{N}$ \\
\hline \multicolumn{5}{|l|}{ Water availability (wa) } \\
\hline Rainfall (mm) & $500-1.200$ & $\begin{array}{c}1.200-1.600 \\
400-500\end{array}$ & $\begin{array}{c}>1.600 \\
300-400\end{array}$ & $<300$ \\
\hline Land use & Rice field & moor & Open land & other \\
\hline $\begin{array}{l}\text { Rooting media }(\mathrm{rc}) \\
\text { texture }\end{array}$ & $\begin{array}{l}\text { smooth, rather } \\
\text { smooth, medium }\end{array}$ & - & $\begin{array}{l}\text { rather } \\
\text { rough }\end{array}$ & rough \\
\hline \multicolumn{5}{|l|}{ Nutrient retention (nr) } \\
\hline CEC clay $(\mathrm{cmol})$ & $>16$ & $\leq 16$ & $<35$ & \\
\hline Base saturation (\%) & $>50$ & $35-50$ & $\begin{array}{l}<5.5 \\
>8.2\end{array}$ & \\
\hline $\mathrm{pH} \mathrm{H} \mathrm{H}_{2} \mathrm{O}$ & $5.8-7.8$ & $\begin{array}{l}5.5-5.8 \\
7.8-8.2\end{array}$ & & \\
\hline $\begin{array}{l}\text { C-Organic }(\%) \\
\text { The danger of erosion (eh) }\end{array}$ & $>0.4$ & $\leq 0.4$ & & \\
\hline Slope $(\%)$ & $<8$ & $8-16$ & $16-30$ & $>30$ \\
\hline
\end{tabular}

Source : Center for Research and Development of Agricultural Land Resources (Indonesia) that have modified. Note : $\mathrm{S} 1=$ very appropriate; $\mathrm{S} 2$ = appropriate; $\mathrm{S} 3$ = less appropriate; $\mathrm{N}=$ no appropriate

Table 7. Analysis of modeling land suitability for maize cultivation in Madura-Indonesia

\begin{tabular}{llcc}
\hline No & Land suitability class & Total (ha) & Procentage $(\%)$ \\
\hline 1 & Very appropriate & $70.379,5$ & 15.4 \\
2 & Appropriate & $211,412,3$ & 46.3 \\
3 & Less appropriate & $160,098.6$ & 35.1 \\
4 & No appropriate & $14,732.0$ & 3.2 \\
& Total & $456,622.3$ & 100.0 \\
\hline
\end{tabular}

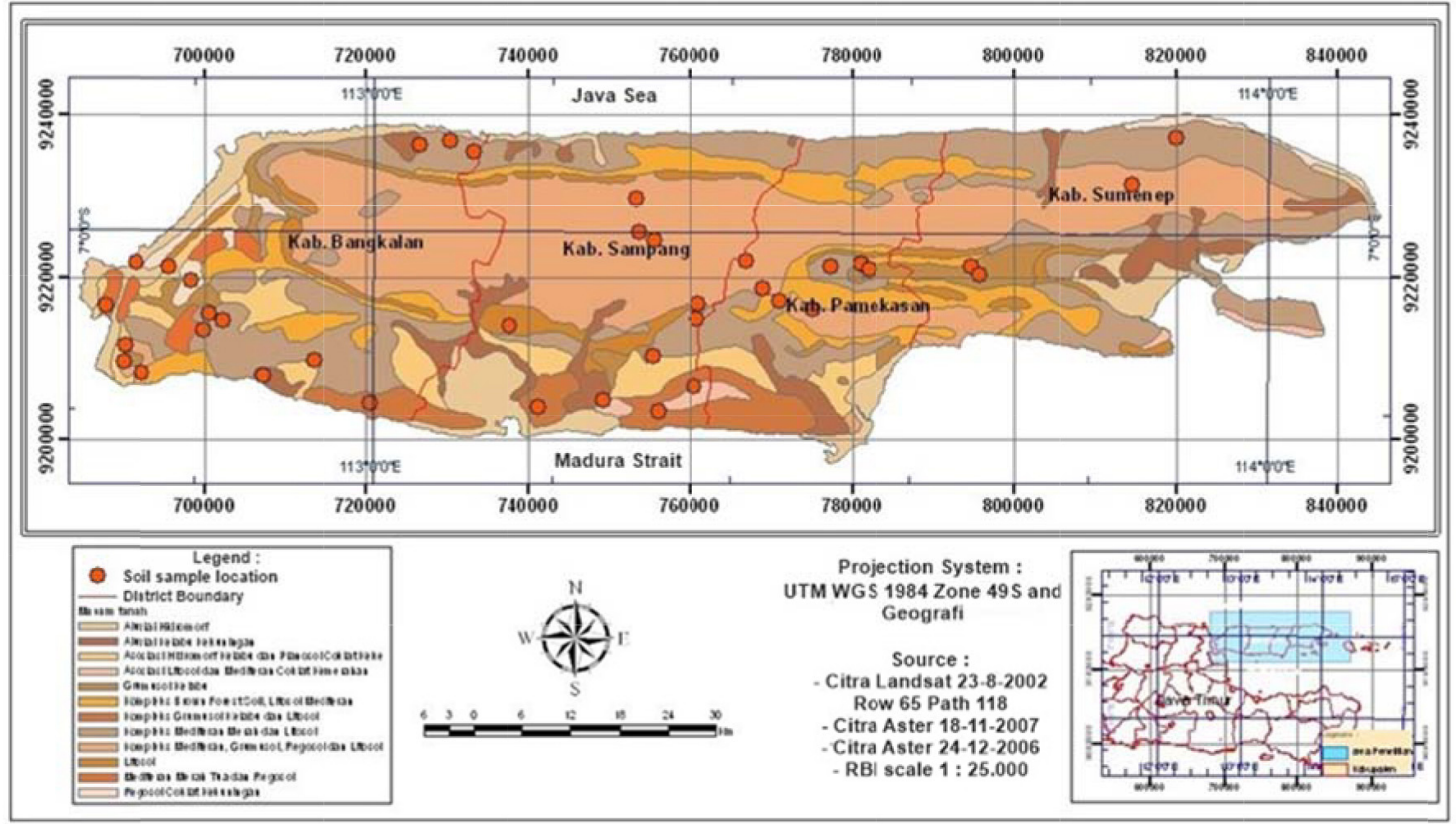

Fig. 6. The location of soil samples in each soil type. 
Table 8. Analysis of the suitability of maize land suitability in four districts of Madura-Indonesia.

\begin{tabular}{|c|c|c|c|c|c|c|c|c|c|}
\hline \multirow[t]{3}{*}{ No. } & \multirow[t]{3}{*}{ Class } & \multicolumn{8}{|c|}{ District } \\
\hline & & \multicolumn{2}{|c|}{ Bangkalan } & \multicolumn{2}{|c|}{ Sampang } & \multicolumn{2}{|c|}{ Pamekasan } & \multicolumn{2}{|c|}{ Sumenep } \\
\hline & & Large (ha) & $\%$ & Large (ha) & $\%$ & Large (ha) & $\%$ & Large (ha) & $\%$ \\
\hline 1 & Very appropriate & $14,001,8$ & 10.8 & $20,247.7$ & 16.4 & $15,188.4$ & 18.6 & $20,941.5$ & 17.3 \\
\hline 2 & Appropriate & $60,996.7$ & 46.9 & $45,195.7$ & 36.6 & $37,547.2$ & 45.9 & $67,672.7$ & 55.7 \\
\hline 3 & Less appropriate & $50,311.1$ & 38.7 & $54,833.0$ & 44.4 & $25,197.0$ & 30.8 & $29,757.4$ & 24,5 \\
\hline 4 & No appropriate & 4.809 .0 & 3.7 & $3,086.0$ & 2.5 & $3,811.3$ & 4.7 & $3,025.6$ & 2,5 \\
\hline & Total & $130,118.6$ & 100.0 & $123,362.5$ & 100.0 & $81,744.0$ & 100.0 & $121,397.2$ & 100.0 \\
\hline
\end{tabular}

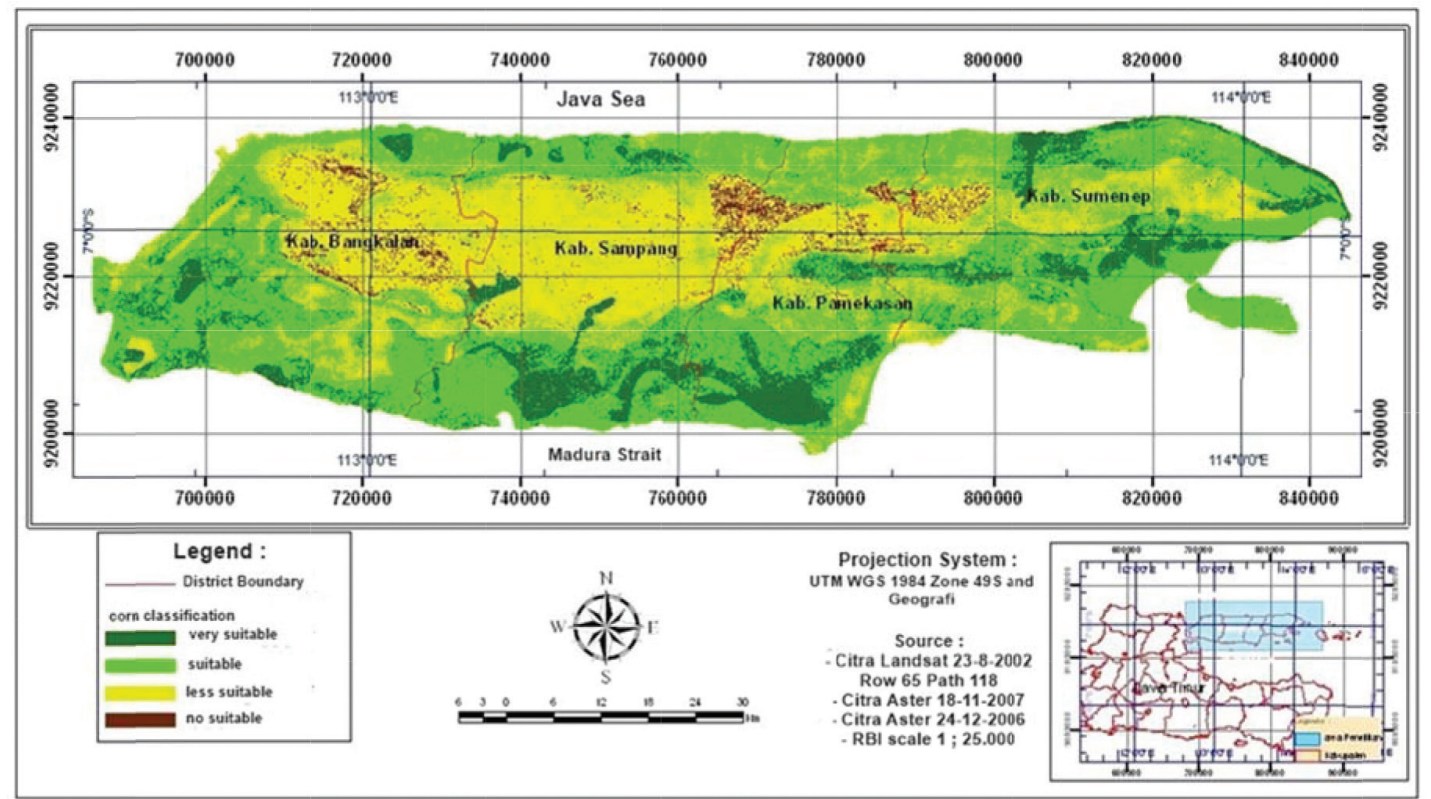

Fig 7. Land suitability map for corn

\section{Conclusion}

The results of the analysis of land suitability modeling based on agroecosystem potential found that most of the Madura area was suitable for maize cultivation. Madura island had a land area of 456,622.3ha for maize cultivation, where 170,379.5 $(15.4 \%)$ was very appropriate, $211,412.3$ ha $(46.3 \%)$ was appropriate, 160,098.6 (35.1\%) was less appropriate, and $14,732.0$ ha (3.2\%) was not appropriate.

\section{References}

Agriculture Ministry of Indonesia 2019. Production, Harvest Area, and Productivity of Palawija in Indonesia, 2014 - 2018. Agriculture Ministry, Indonesia.

Al Ramahi, F.K.M., Jasim, M.S. and Rasheed, M.J. 2020. To study climatic factors effect on Land Covers (LC) for Salah Aldeen region by using remote sensing data.
Eco. Env. E Cons. 26 (1) : 446-453.

Arsyad, Sitanala, 1989. Soil Erosion and Conservation. Bogor Agricultural Institute, Indonesia.

BPS, 2019. Report on Indonesia's harvested area, productivity, and maize production in 2014-2018. Jakarta, Indonesia.

CRS/FAO Staff, 1983. Reconnaissance Land Resources Survey, Atlas Format Producedur. CRS. Bogor, Indonesia.

Directorate of Land Processing, 2006. Land Management Problems in Indonesia. National Seminar Paper at the Faculty of Agriculture, UNS, Surakarta. Indonesia.

Edgerton, M.D. 2009. Increasing Crop Productivity to Meet Global Needs for Feed, Food, and Fuel. Plant Physiology. 149: 7-13. DOI: https://doi.org/10.1104/ pp.108.130195.

Kasryno, F., Effendi, P., Suyamto and Adnyana, M.O. 2007. An Overview of Indonesian Maize. Center for Research and Development of Food Crops, Indonesia.

Malinggreau, J.P. 1982. A Land Cover/ Land Use Classification for Indonesia. PUSPICS, Gadjah Mada Univer- 
sity. Yogyakarta, Indonesia.

Mujiyo, Sumani, Noorhadi, 2008. Mapping the transfer of function of agricultural land with GIS and Remote Sensing. Caraka Tani. 13 (1) : 13-17, DOI: https:/ / doi.org/10.20961/carakatani.v23i1.13826.

Nugroho, B.A. 2015. Analysis of Production Functions and Efficiency of Corn at Patean District Kendal Regency. Jejak. 8 (2) : 160-172. DOI: http:/ /dx.doi.org/ 10.15294/jejak.v8i2.6168.

Ranum, P., Pena-Rosas, J.P., Garcia-Casal, M.N. 2014. Global maize production, utilization, and consumption.
Ann. N.Y. Acad. Sci. 1312 : 105-112. DOI: 10.1111/ nyas.12396.

Roesmarkam S, Arifin F, Sa'adah SZ, Abu, Robi'in, 2006. Proposed bleaching of local varieties of Madura Maize: Manding, Talango and Guluk-guluk. Institute for Agricultural Technology Assessment - East Java, Indonesia.

Salih A, 2018. Classification and Mapping of Land Cover Types and Attributes in AlAhsaa Oasis, Eastern Region, Saudi Arabia Using Landsat-7 Data. J Remote Sensing E GIS. 7:1. DOI:10.4172/2469-4134.1000228. 